\title{
TCOM \\ Examining the relationship between gene editing knowledge, value predispositions, and general science attitudes among U.S. farmers, scientists, policymakers, and the general public
}

\section{Christopher Calabrese, Jieyu Ding Featherstone, Matthew Robbins and George A. Barnett}

\begin{abstract}
Science communication scholars have debated over what factors are related to public support for science and technology. This study examines the relationship between factual knowledge of gene editing technologies, value predispositions, and general science attitudes among four major U.S. agricultural stakeholder groups: farmers, scientists, policymakers, and the general public. Understanding these factors will aid in guiding message strategies for engagement with stakeholder groups. Findings indicate that gene editing knowledge was positively associated with science attitudes for all four groups, while conservative ideology was negatively associated with science attitudes among three of the groups. Implications and limitations are discussed.
\end{abstract}

Keywords

DOI

Public perception of science and technology; Public understanding of science and technology

https://doi.org/10.22323/2.20020202

Submitted: 15th September 2020

Accepted: 23rd November 2020

Published: 15th February 2021

Introduction

Scientists have debated what factors are related to support for science and technology. Previously, some scholars advocated for the "scientific literacy model", which assumed that scientific knowledge is the key factor that influences science attitudes [Miller, 1983; Miller, 1998], though widely debated. Other scholars have since indicated that cognitive shortcuts, such as value predispositions, mainly influence attitudes [Fiske and Taylor, 1991]. However, recent studies reveal that the relationship between scientific knowledge and attitudes is more nuanced where the strength of knowledge on attitudes is moderated by value predispositions, such as religiosity [Allum, Sibley et al., 2014; Brossard, Scheufele et al., 2009].

Despite the potential benefits new technologies may bring to society, they often face varying levels of public acceptance [Rogers, 2003]. For example, public views 
surrounding the risks and benefits of genetically modified (GM) foods in the U.S. are still fairly mixed [Kennedy, Hefferon and Funk, 2018]. Similarly, support for gene editing, an advanced tool used to precisely "cut and replace" sequences of DNA, is dependent upon how the tool is applied [Calabrese, Anderton and Barnett, 2019; Gaskell et al., 2017; Scheufele et al., 2017]. Gene editing is a more precise tool of genetic engineering, and includes technologies such as CRISPR-Cas9, zinc finger nucleases (ZFNs), and transcription activator-like effector nucleases (TALENs); this difference has prompted efforts to "rebrand" the term to shift away from current perceptions of GM foods [Doxzen and Henderson, 2020]. Understanding how knowledge of emerging technologies, such as gene editing, influences individuals' attitudes will aid in the development of message strategies to foster meaningful discussions and debates among key publics.

The present, correlational study investigates how gene editing and biotechnology knowledge and value predispositions, such as ideology and religiosity, may be associated with general science attitudes. In addition, it examines the influence of value predispositions on moderating the relationship between knowledge and attitudes. This study is part of a larger project to understand individuals' knowledge and perceptions of gene editing in agriculture. Thus, four key U.S. stakeholder groups are assessed, including farmers, genetics and genomics research scientists, policymakers, and the general public. These stakeholder groups are likely to have different goals and intentions regarding new technologies [Post and Maier, 2016]. Therefore, examining how domain-specific knowledge and value predispositions are associated with attitude toward science in general among these groups will be particularly helpful in guiding targeted engagement strategies for innovations in agriculture. To our knowledge, this study is one of the first to examine the relationship between gene editing technology knowledge and value predispositions with general science attitudes among multiple major stakeholder groups in the U.S.

\section{Gene editing technology}

Advancements in gene editing technologies have improved the ways in which scientists can edit sequences of DNA within an organism's genome. The ability to "cut and replace" precise DNA sequences provides potential opportunities for improving agriculture and medicine. For example, gene editing technology has been used as a tool for developing disease-resistant rice [S. Li et al., 2019; T. Li et al., 2012], and as a method to provide potential treatment for muscular dystrophy, where steps have been taken with dog and mouse models [Amoasii et al., 2018; Long et al., 2016; Min et al., 2019]. Despite the potential benefits of gene editing, there may be several moral and ethical issues involved with the technology. For example, recent news of gene editing research on human embryos sparked major discussions surrounding the moral and ethical implications of the technology [Calabrese, Anderton and Barnett, 2019; Regalado, 2018]. Because emerging technologies have their own potentially positive and negative implications, it is important to understand the public's knowledge, as well as their views towards these new scientific innovations.

In general, people are more in favor of gene editing applications when used for health and medical reasons, but are against its use for human enhancements [Funk 
and Hefferon, 2018; Gaskell et al., 2017; Scheufele et al., 2017]. For example, Funk and Hefferon [2018] found roughly $72 \%$ of U.S. adults were accepting of gene editing applications on human embryos for the purpose of treating a disease, while $80 \%$ were against its use for increasing babies' intelligence. However, there are several factors shown to influence acceptance of the technology. Scheufele et al. [2017] found individuals who scored lower in levels of religious guidance and those who had higher factual knowledge were more likely to support gene editing for treatment of human disease. Similarly, highly religious individuals were more opposed to the use of gene editing on embryos, while those with more general science knowledge had higher acceptance of its use [Funk and Hefferon, 2018]. Less is known about the public's views of gene editing for non-human applications, such as for farming and agriculture. One study found that most U.S. adults believed gene editing for wildlife conservation was more risky, citing that the technology may be misused by those who have bad intentions [Kohl et al., 2019].

Past research suggests there can be a positive association between scientific knowledge and attitudes [Allum, Sturgis et al., 2008]. While some studies have found a relationship between gene editing knowledge and attitudes [Scheufele et al., 2017], it is also important to explore how gene editing knowledge is related to general attitudes toward science. Such research will provide an understanding of whether domain-specific knowledge is associated with science attitudes in general among different key publics.

\section{Role of science knowledge}

Previous research in science communication has often built upon the assumption that unfavorable attitudes toward science and technology are influenced by a lack of information, and improving scientific literacy will increase public support of science and technology [Miller, 1983; Miller, 1998]. Known as the deficit model, this idea has had some support with several empirical studies, including a meta-analysis that found a consistent positive association between scientific knowledge and general science attitudes [Allum, Sturgis et al., 2008]. It is important to note, however, that among science communication scholars, the relationship between knowledge and attitudes is believed to be more nuanced [Simis et al., 2016]. Further, a number of studies have found results at odds with the deficit model [Connor and Siegrist, 2010; Lee and Kim, 2018] citing that other factors may also play a role in attitudes.

In the context of biotechnology, research also suggests that specific science knowledge plays a role in people's beliefs. For example, Kato-Nitta et al. [2019] examined the influence of domain-specific knowledge on attitudes toward gene editing, genetic modification, and conventional breeding for agricultural crops among Japanese scientists and general publics; they found that knowledge significantly influenced beliefs on the benefits of the breeding technologies. Specific knowledge may provide individuals with a developed understanding to make informed decisions surrounding the technologies.

To further explore the relationship between knowledge and attitudes, and test whether this association holds in the context of gene editing, this study first examines the relationship between gene editing knowledge and science attitudes 
among four key U.S. publics: farmers, scientists, policymakers, and the general public. In line with the assumptions of the deficit model, specific scientific knowledge may be related to an individuals' science attitudes in general. We propose the following hypothesis:

H1: Gene editing knowledge will be positively associated with general science attitudes among stakeholder groups.

\section{Role of value predispositions}

While there is some support for the deficit model [Miller, 1983] though studies have found inconsistent results [Connor and Siegrist, 2010; Lee and Kim, 2018], some argue that people use heuristic shortcuts to form their attitudes instead of seeking out new information themselves [Ho, Brossard and Scheufele, 2008]. This "cognitive misers" model suggests that predispositions, such as religiosity and political ideology, play a large role for forming opinions toward a particular subject [Fiske and Taylor, 1991]. Religiosity, which we define as the level of devotion one has to their religion, may influence attitudes toward science topics; for example, individuals may believe that gene editing is messing with God's creation [Walker and Malson, 2020], and subsequently may have negative attitudes toward science in general. Similarly, political ideology may influence science attitudes, where those who are more conservative may have more negative views toward science topics [Kohl et al., 2019; Newman, Nisbet and Nisbet, 2018].

For example, Scheufele et al. [2017] found that conservative political ideology and religiosity where negatively related to support for medical applications of human gene editing. Based on the "cognitive misers" model [Fiske and Taylor, 1991], value predispositions may have a significant influence on general attitudes toward science. Thus, we propose the following hypothesis:

H2: Value predispositions, such as a) conservative ideology and b) religiosity, will be negatively associated with general science attitudes among stakeholder groups.

\section{Moderation effects and demographics}

Others argue that the formation of science attitudes are more nuanced, and may be influenced by several factors [Allum, Sibley et al., 2014; Brossard, Scheufele et al., 2009]. Brossard, Scheufele et al. [2009] found that support for federal funding of nanotechnology varied by religiosity, where individuals who had high nanotechnology knowledge and low religiosity supported more federal funding. To assess the potential complexities of science attitude formation, we propose the following research question:

RQ1: How do value predispositions influence the relationship between gene editing knowledge and general science attitudes? 
Lastly, understanding the potential relationship with demographic variables for each stakeholder group will help guide group-based message strategies for increasing support toward emerging technologies. Thus, it is important to examine whether demographic characteristics may influence individuals' attitudes toward science. We propose the following research question:

RQ2: What demographic variables are associated with general science attitudes among stakeholder groups?

All study procedures were approved by the institution's review board. Both the general public and farmers samples were recruited through Qualtrics panels (https://www.qualtrics.com/), an online sampling platform. For the general public stakeholder group, quotas were set to recruit a sample of participants that reflected the U.S. population based on census data. The farmers sample was recruited from an online Qualtrics panel of farmers throughout the U.S.

To obtain samples for the scientist and policymaker stakeholder groups, recruitment was conducted through online invitations. We defined scientists as tenure-track professors in genetics or genomics from land grant institutions of the 11 states producing the greatest dollar value from agriculture: California, Iowa, Texas, Nebraska, Minnesota, Illinois, Kansas, North Carolina, Wisconsin, and Indiana (https:/ / www.ers.usda.gov/faqs/), since the focus of this research was on the application of gene editing in agriculture. Land-grant universities were classified according to the Land-Grant Agricultural and Mechanical College Act of 1862. A database of all tenure-track professors in genetics or genomics from each land-grant institution was collected through an online web search. Potential participants were scraped from each university's website when available; eligibility criteria included being a tenure-track professor of a "genetics" or "genomics" department or program, or if the professor included "genetics" or "genomics" in their research interests. A total of 13 universities emerged with 817 scientists. Scientists from these institutions were sent an email requesting their participation in a survey assessing their thoughts and opinions toward gene editing technologies.

Policymakers were recruited through an email requesting participation in the same survey. The U.S. congressional staff, as well as California Department of Food and Agriculture (CDFA) personnel, were both recruited for this study. Since the focus of this research is on the application of gene editing in agriculture, a congressional contact list of staffers working in science and technology or agriculture and food was purchased from a third-party source, LegiStorm

(https:/ /www.legistorm.com/). A total of 519 staffers were contacted. The CDFA members were recruited by email, with the department commissioner's endorsement. The samples from the congressional staff and the CDFA did not statistically differ in knowledge, attitudes, or any demographic variable aside from age, and thus were combined into one policymaker sample.

Qualtrics Labs, Inc. software (Provo, UT, version 12) was used as the survey platform to conduct the survey. First, participants viewed the consent page, then 
answered questions assessing their gene editing and biotechnology knowledge, their attitude toward science, political ideology, religiosity, and demographics. Participants were compensated after study completion.

\section{Measures}

Gene editing and biotechnology knowledge was measured through a scale developed by the researchers modeled from previous studies [Scheufele et al., 2017; Usak et al., 2009]. Table 1 depicts the items used for the knowledge scale. Items were developed in conjunction with a biologist to ensure accuracy. Three rounds of pretesting were samples with undergraduate students that resulted in a 23-item knowledge scale with high reliability $(\alpha=.87)$. Respondents either answered "True", "False", or "Unsure". The correct answer was coded as "1", while the incorrect answer or "Unsure" was coded as " 0 ". Research suggests that those who select "Unsure/Don't know" as a response to knowledge questions have no knowledge of the true answer [Luskin and Bullock, 2011]; thus, "Unsure" was coded as "0", in line with previous studies [Scheufele et al., 2017]. Scores were assessed by percent correct and ranged from 0 to 1 .

Table 1. Gene editing and biotechnology knowledge items.

\begin{tabular}{l}
\hline Item \\
Genetically modified organisms are always bigger than normal. \\
Genetic modification is painful for animals. \\
It is easy to detect whether an animal or crop has been genetically modified by looking at \\
them. \\
Consumption of genetically modified food can destroy human genes. \\
Genetically modified organisms are radioactive. \\
Genetically modified crops are sterile. \\
Genetically modified animals are less healthy than their "conventional" counterparts. \\
Eating genetically modified foods can increase the level of toxins the body produces. \\
A common genetically modified trait in plants is bee resistance. \\
Consumption of genetically modified food can change the genetic makeup of humans. \\
Genetically modified organisms are hazardous to bees. \\
Some genetically modified plants produce a bacterial toxin. \\
Genetically modified foods are treated with pesticides, whereas organic foods are not. \\
Viral genes can be picked up by other species in a lab. \\
Some U.S. universities are currently fighting in court over who owns the patent for the \\
gene editing technology CRISPR-Cas9. \\
Viral genes can be picked up by other species in nature. \\
A genome contains our genetic code. \\
A genome is written in a code of four letters - A, T, C, G. \\
A genome can be interpreted as the instruction manual for an organism. \\
Genome editing is a research tool used to make changes to the genome. \\
Genome editing has been used to cure or treat diseases, such as leukemia, in humans. \\
Genome editing is a tool used to determine the sequence of the DNA code. \\
\hline
\end{tabular}


Attitude toward science was measured through a scale adapted from previous research [Funk, Rainie and Page, 2015; National Science Board, 2018]. After three rounds of pretesting with samples of undergraduate students, a 16-item attitude scale emerged $(\alpha=.87)$. The measure was assessed on 5-point Likert scales (from $1=$ strongly negative to $5=$ strongly positive, and from $1=$ strongly disagree to $5=$ strongly agree). Respondents viewed statements such as: Biological research has helped advance medicine. Science and technology are making our lives healthier. However, one item was dropped from this analytical sample due to poor reliability. See Table 2 for the general attitude scale items.

Table 2. The general science attitudes scale.

Item
Has science had a strongly negative or strongly positive effect on the quality of food in
Has science had a strongly negative or strongly positive effect on the quality of health
care in the U.S.?
Has science had a strongly negative or strongly positive effect on the quality of the envir-
onment in the U.S.?
Please indicate whether you agree or disagree with the following statements:
Biological research has helped advance medicine.
Biological research has helped advance our food system.
Science and technology are making our lives healthier.
Science and technology are making our lives easier.
Science and technology are making our lives more comfortable.
The benefits of science are greater than any harmful effects.
Even if it brings no immediate benefits, scientific research that advances the frontiers of
knowledge is necessary.
Even if it brings no immediate benefits, scientific research that advances the frontiers of
knowledge should be supported by the federal government.
I have confidence in the people running the scientific research community in this country.
Scientists are helping to solve challenging problems.
Most scientists want to work on things that will make life better for the average person.
Because of science and technology, there will be more opportunities for the next genera-
tion.

Note: Items $1-3$ were coded from $1=$ strongly negative to $5=$ strongly positive. Items $4-12$ were coded from $1=$ strongly disagree to $5=$ strongly agree.

Political ideology was assessed on a 5-point scale from 1 (very liberal) to 5 (very conservative). Religiosity was measured through a one item statement, "How often do you attend religious services?" from 0 (never) to 4 (several times a week). This item has been used in previous studies to assess religiosity [Wilkes, Burnett and Howell, 1986], and served as a proxy to assess how important participants view their religion.

Demographic variables, such as age and gender, were also assessed. For analysis, gender was coded as either "Female" or "Not female". Race was measured by the question, "What is your race/ethnicity?" with options to select any of the following that apply, "White/Caucasian", "Black/African American", "Asian", "Hispanic/Latino", and "Other". Based on the small sample sizes, race was 
dummy coded as either "White" or "Non-white" for analysis. Education was assessed through the question, "What is the highest degree you received?" and was categorized into "Less than high school", "HS graduate", "Associates degree/Some college", "Bachelor degree", "Master's degree", and "Doctorate/Professional degree". Income was only measured for the general public as a method to ensure a U.S. census-matched sample by Qualtrics; the question asked participants to indicate their entire household income during the previous year before taxes.

\section{Analysis}

Means and standard deviations of each stakeholder group's knowledge and attitudes were first conducted. Then, ANOVA and Tukey's post-hoc comparison tests were conducted to assess differences between the samples in knowledge and attitudes. To answer the hypotheses and research questions, regression analyses were conducted to test the hypothesized variables with science attitudes for each of the four samples. The first set of regression models included gene editing knowledge, value predispositions, and demographic variables, while the second set of regression models also included interaction terms to answer the first research question. Analyses were conducted in R Version 3.6.0 and SPSS Version 26.

Table 3 displays the demographic characteristics among each sample. Means, standard deviations, and reliability of the gene editing and biotechnology knowledge and science attitude scales are shown in Table 4. Results from ANOVA revealed that there was a significant difference in knowledge between stakeholder groups, $F(3,1103)=275.10, p<.001$. Post-hoc analyses uncovered that all four samples differed from one another; scientists had the highest knowledge $(M=.89)$, followed by policymakers $(M=.66)$, farmers $(M=.46)$, and the general public $(M=.41)$.

For attitude toward science, there was a significant difference between stakeholder groups, $F(3,1003)=62.27, p<.001$. Post-hoc analyses found that scientists had the most positive attitudes $(M=4.58)$, followed by policymakers $(M=4.20)$, and lastly farmers $(M=3.78)$ and the general public $(M=3.86)$. There was no significant difference in attitudes between farmers and the general public. Despite the unequal sample sizes between stakeholder groups, results for gene editing knowledge and general science attitudes were robust to subsequent analyses using Welch's tests.

\section{Regression analyses}

Regression analyses revealed that gene editing knowledge were significantly associated with science attitudes across all four stakeholder groups controlling for value predispositions and demographic variables (see Table 5). For the general public, the model explained $18 \%$ of the variance on general science attitudes. Gene editing knowledge was significantly related to science attitudes $(\beta=.28, p<.001)$. Further, conservatism was negatively associated with science attitudes $(\beta=-.08$, 
Table 3. Sample characteristics across stakeholder groups.

\begin{tabular}{|c|c|c|c|c|c|c|c|c|}
\hline & \multicolumn{2}{|c|}{$\begin{array}{l}\text { General public } \\
\qquad(\mathrm{N}=621)\end{array}$} & \multicolumn{2}{|c|}{$\begin{array}{l}\text { Farmers } \\
(\mathrm{N}=210)\end{array}$} & \multicolumn{2}{|c|}{$\begin{array}{l}\text { Policymakers } \\
\qquad(\mathrm{N}=94)\end{array}$} & \multicolumn{2}{|c|}{$\begin{array}{l}\text { Scientists } \\
(\mathrm{N}=182)\end{array}$} \\
\hline & $\mathrm{n}$ & $\%$ & $\mathrm{n}$ & $\%$ & $\mathrm{n}$ & $\%$ & $\mathrm{n}$ & $\%$ \\
\hline Female & 291 & 46.9 & 107 & 51.0 & 42 & 44.7 & 58 & 31.9 \\
\hline White race ${ }^{\mathrm{a}}$ & 477 & 76.8 & 170 & 81.0 & 65 & 69.1 & 135 & 74.2 \\
\hline Age, M (SD) & 45.6 & $(17.0)$ & 41.0 & $(14.8)$ & 41.1 & $(14.3)$ & 52.2 & $(10.3)$ \\
\hline Liberal-conservative $^{\mathrm{b}}, \mathrm{M}$ (SD) & 3.0 & $(1.2)$ & 3.0 & $(1.1)$ & 3.1 & $(1.0)$ & 2.3 & $(.9)$ \\
\hline \multicolumn{9}{|l|}{ Religion } \\
\hline Protestant & 163 & 26.2 & 51 & 24.3 & 20 & 21.3 & 33 & 18.1 \\
\hline Catholic & 118 & 19.0 & 64 & 30.5 & 20 & 21.3 & 17 & 9.3 \\
\hline Muslim & 33 & 5.3 & 6 & 2.9 & 0 & 0 & 8 & 4.4 \\
\hline Jewish & 15 & 2.4 & 6 & 2.9 & 1 & 1.1 & 2 & 1.1 \\
\hline Other & 140 & 22.5 & 34 & 16.2 & 15 & 16.0 & 20 & 11.0 \\
\hline None & 152 & 24.5 & 49 & 23.3 & 38 & 40.4 & 102 & 56.0 \\
\hline Religiosity $^{\mathrm{c}}, \mathrm{M}(\mathrm{SD})$ & 1.0 & $(1.4)$ & 1.1 & $(1.5)$ & .5 & $(1.0)$ & .8 & $(1.4)$ \\
\hline \multicolumn{9}{|l|}{ Education } \\
\hline Less than HS & 15 & 2.4 & 4 & 1.9 & 0 & 0 & & \\
\hline HS diploma & 147 & 23.7 & 55 & 26.2 & 4 & 4.3 & & \\
\hline Associate degree & 185 & 29.8 & 55 & 26.2 & 10 & 10.6 & & \\
\hline Bachelor's degree & 139 & 22.4 & 56 & 26.7 & 39 & 41.5 & & \\
\hline Master's degree & 94 & 15.1 & 28 & 13.3 & 23 & 24.5 & & \\
\hline Doctorate & 41 & 6.6 & 12 & 5.7 & 18 & 19.1 & & \\
\hline \multicolumn{9}{|l|}{ Income } \\
\hline Less than $\$ 49,999$ & 231 & 37.2 & & & & & & \\
\hline$\$ 50,000-\$ 99,999$ & 215 & 34.6 & & & & & & \\
\hline$\$ 100,000$ or more & 174 & 28.0 & & & & & & \\
\hline
\end{tabular}

Note: Income was assessed in the general public survey. Based on our definition of scientists, education was not included as a variable in the group's analyses.

a Reference category, non-White race.

b Liberal-conservative was measured on a scale from 1 (very liberal) to 5 (very conservative).

${ }^{\mathrm{c}}$ Religiosity was measured on a scale from 0 (never) to 4 (several times a week).

$p=.048)$, and income $(\beta=.16, p<.001)$ and education level $(\beta=.09, p=.043)$ were also associated with science attitudes.

For farmers, $22 \%$ of the variance was explained by the model. Gene editing knowledge had a significant positive relationship with science attitudes $(\beta=.25$, $p<.001)$. Being more conservative had a negative influence on science attitudes $(\beta=-.15, p=.02)$, while race $(\beta=.20, p=.002)$ and education $(\beta=.23, p=.001)$ had a significant positive relationship with science attitudes.

Among policymakers, gene editing knowledge had a strong positive relationship with science attitudes $(\beta=.49, p<.001)$. Conservatism was negatively associated 
Table 4. Means, standard deviations, and reliability across stakeholder groups.

\begin{tabular}{|l|c|c|c|c|c|c|c|c|c|c|c|c|l|l|}
\hline & $\begin{array}{c}\text { General public } \\
(\mathrm{N}=621)\end{array}$ & \multicolumn{2}{|c|}{$\begin{array}{c}\text { Farmers } \\
(\mathrm{N}=210)\end{array}$} & \multicolumn{2}{c|}{$\begin{array}{c}\text { Policymakers } \\
(\mathrm{N}=94)\end{array}$} & \multicolumn{2}{c|}{$\begin{array}{c}\text { Scientists } \\
(\mathrm{N}=182)\end{array}$} & \multicolumn{2}{c|}{$\begin{array}{c}\text { Overall } \\
(\mathrm{N}=1107)\end{array}$} \\
\hline Variable & $\mathrm{M}$ & $\mathrm{SD}$ & $\alpha$ & $\mathrm{M}$ & $\mathrm{SD}$ & $\alpha$ & $\mathrm{M}$ & $\mathrm{SD}$ & $\alpha$ & $\mathrm{M}$ & $\mathrm{SD}$ & $\alpha$ & $\begin{array}{l}\text { Test } \\
\text { statistic }\end{array}$ & $p$-value \\
\hline $\begin{array}{l}\text { GE\&BT } \\
\text { knowledge }\end{array}$ & .41 & .23 & .84 & .46 & .20 & .79 & .66 & .24 & .89 & .89 & .09 & .56 & $\begin{array}{l}F(3,1103) \\
=275.10\end{array}$ & $p<.001$ \\
\hline $\begin{array}{l}\text { Science } \\
\text { attitudes }\end{array}$ & 3.86 & .70 & .93 & 3.78 & .85 & .95 & 4.20 & .58 & .91 & 4.58 & .37 & .85 & $\begin{array}{l}F(3,1003) \\
=62.27\end{array}$ & $p<.001$ \\
\hline
\end{tabular}

Note: GE\&BT, Gene Editing and Biotechnology.

Knowledge was measured by percent correct from 0 to 1 .

Science attitudes were assessed on a scale from 1 (strongly disagree) to 5 (strongly agree).

Table 5. Regression analysis of gene editing knowledge on science attitudes across stakeholder groups.

\begin{tabular}{|l|c|c|c|c|c|c|c|c|c|c|c|c|}
\hline & \multicolumn{3}{|c|}{$\begin{array}{l}\text { General public } \\
(\mathrm{N}=621)\end{array}$} & \multicolumn{3}{c|}{$\begin{array}{c}\text { Farmers } \\
(\mathrm{N}=210)\end{array}$} & \multicolumn{3}{c|}{$\begin{array}{c}\text { Policymakers } \\
(\mathrm{N}=94)\end{array}$} & \multicolumn{3}{c|}{$\begin{array}{c}\text { Scientists } \\
(\mathrm{N}=182)\end{array}$} \\
\hline Variable & $B$ & $S E B$ & $\beta$ & $B$ & $S E B$ & $\beta$ & $B$ & $S E B$ & $\beta$ & $B$ & $S E B$ & $\beta$ \\
\hline $\begin{array}{l}\text { GE\&BT } \\
\text { knowledge }\end{array}$ & .83 & .12 & $.27^{* * *}$ & 1.08 & .27 & $.25^{* * *}$ & 1.19 & .22 & $.49^{* * *}$ & 1.5 & .30 & $.35^{* * *}$ \\
\hline Age & .00 & .00 & .01 & .00 & .00 & -.00 & -.00 & .00 & -.08 & .00 & .00 & .04 \\
\hline Female & -.05 & .06 & -.04 & -.16 & .11 & -.09 & -.14 & .10 & -.18 & .04 & .06 & .05 \\
\hline White race & .05 & .06 & .03 & .44 & .14 & $.20^{* *}$ & .27 & .11 & $.22^{*}$ & .04 & .06 & .04 \\
\hline Education & .06 & .03 & $.10^{*}$ & .16 & .05 & $.23^{* *}$ & -.04 & .05 & -.08 & & & \\
\hline $\begin{array}{l}\text { Liberal- } \\
\text { conservative }\end{array}$ & -.04 & .02 & $-.07^{*}$ & -.11 & .05 & $-.15^{*}$ & -.14 & .06 & $-.25^{*}$ & -.00 & .03 & -.00 \\
\hline Religiosity & .03 & .02 & .05 & .06 & .03 & -.11 & .13 & .06 & $.22^{*}$ & -.04 & .02 & $-.13^{\#}$ \\
\hline Income & .03 & .01 & $.15^{* *}$ & & & & & & & & & \\
\hline$R^{2}$ & & .19 & & & .24 & & & .38 & & & .15 & \\
\hline Adj. $R^{2}$ & & .18 & & & .22 & & & .34 & & & .12 & \\
\hline
\end{tabular}

Note: GE\&BT, Gene Editing and Biotechnology.

Income was assessed in the general public survey.

Based on our definition of scientists, education was not included as a variable in the group's regression analyses.

a Reference category, non-White race.

${ }^{\mathrm{b}}$ Liberal-conservative was measured on a scale from 1 (very liberal) to 5 (very conservative).

${ }^{\mathrm{c}}$ Religiosity was measured on a scale from 0 (never) to 4 (several times a week).

${ }^{\#} p<.10$

$* p<.05$

** $p<.01$

*** $p<.001$

with science attitudes $(\beta=-.25, p=.022)$. Race $(\beta=.22, p=.019)$ and religiosity $(\beta=.22, p=.026)$ had a significant, positive relationship with science attitudes. About $34 \%$ of the variance was explained by the model.

Among scientists, gene editing knowledge had a positive relationship with science attitudes $(\beta=.35, p<.001)$. Value predispositions and demographic variables did not influence science attitudes among scientists, though religiosity had a negative 
marginal association with science attitudes $(\beta=-.13, p=.087)$. The model explained $12 \%$ of the variance for the scientists.

Overall, gene editing knowledge was positively associated with general science attitudes for each stakeholder group; thus, H1 was supported. Conservative political ideology was negatively associated with general science attitudes among farmers, policymakers, and the general public. Religiosity was positively associated with general science attitudes for the policymakers only. Thus, H2a was partially supported, and $\mathrm{H} 2 \mathrm{~b}$ was not supported.

Subsequent regression analyses revealed no significant moderation of political ideology or religiosity on the relationship between gene editing knowledge and general science attitudes, indicating that gene editing knowledge and value predispositions played an independent role on general science attitudes.

Discussion

This study assessed the relationship between gene editing knowledge, value predispositions, and demographic variables with general science attitudes, and is one of the first to test this relationship among four prominent U.S. agricultural stakeholder groups: farmers, scientists, policymakers, and the general public. We find that gene editing knowledge is positively associated with general science attitudes for all four groups controlling for demographic variables, whereas value predispositions and demographic variables of science attitudes varied by stakeholder group.

Among the stakeholder groups, scientists had the highest level of gene editing knowledge, as well as the most positive attitude toward general science. This is unsurprising; however, it is notable that no other variables influenced scientists' general science attitudes. Both religiosity and political ideology did not have a significant influence on science attitudes. This is important because other publics may rely on scientists to disseminate new information and knowledge to the public.

After scientists, policymakers scored highest in knowledge among stakeholder groups. Congressional staff that focus on science and technology or agriculture and food, as well as CDFA personnel, need to make informed decisions when dealing with new policies and regulations surrounding new technologies. In this way, it is understandable that policymakers have higher knowledge about gene editing than farmers and the general public. Also, policymakers had significantly more positive attitudes compared to farmers and the general public. Again, this is an encouraging finding because positive attitudes toward science may lead to more support for policies relating to scientific advancements. Further, because policymakers generally represent large groups of people, having positive attitudes toward science may aid in providing balanced, or at least positive, information surrounding scientific advancements to their represented groups.

We found some evidence of value predispositions influencing general science attitudes, particularly with political ideology. While previous research has found evidence for conservative support of biotechnology [Brossard and Nisbet, 2007; Rose et al., 2019], we find that conservative ideology was associated with more negative general science attitudes among the general public, policymakers, and farmers. This is in line with previous research findings that conservative ideology 
was associated with lower perceptions of the benefits of gene editing for wildlife conservation [Kohl et al., 2019], as well as some other topics, such as climate change concerns [Newman, Nisbet and Nisbet, 2018] and vaccination attitudes [Baumgaertner, Carlisle and Justwan, 2018]. Conservative individuals may show stronger concerns for some negative implications of certain scientific advancements. Tailoring future messages strategies to highlight conservative values may help improve attitudes toward sciences in general, and specifically toward genetic editing.

Religiosity was associated with more positive attitudes toward science for only the policymaker stakeholder group. This runs counter to previous studies finding that religiosity was negatively associated with attitudes toward science topics, such as nanotechnology or gene editing [Brossard, Scheufele et al., 2009; Scheufele et al., 2017]. Religiosity may play a larger role for specific scientific topics, rather than influencing attitude toward science in general.

Interestingly, higher education level was positively associated with attitudes toward science for both farmers and the general public. Educational background may play a larger role in science attitude formation among those with less domain-specific knowledge. Similarly, for the general public, income was strongly associated with science attitudes, which may indicate that one's individual background also plays a role in attitude formation. It is important to note that among farmers and policymakers, being White was positively associated with general science attitudes. This may indicate a need to further engage with minority farmers and policymakers to aid in both addressing issues and informing about new technologies.

The purpose of this study was to examine key factors associated with attitudes toward science. This will ultimately aid in the development of engagement strategies with key audiences. Because gene editing technologies are relatively new to non-expert stakeholder groups, it is important to understand the level of knowledge surrounding these technologies, as well as the values that may play a role in their science attitudes. These findings provide a basis for future work in engaging with key stakeholder groups, fostering meaningful discussions to inform future policies regarding these new technologies [Christopherson, Scheufele and Smith, 2018; Doxzen and Henderson, 2020; Nisbet, 2018]. In light of a rapidly growing world population and accelerating global climate change, it will be increasingly important to gain support for gene editing technologies through engagement with farmers, policymakers, and the general public.

Our knowledge scale was highly reliable for the general public, farmers, and policymakers; however, the reliability of the measure was low for scientists. This may be due to the initial intention of developing a knowledge scale that could be utilized for the general public. Since scientists have a vast understanding of the nuanced complexities of the field, our scale may have been too vague to precisely measure their knowledge. This scale may better serve as a measure for non-expert publics. Despite this limitation, our results suggest that scientific knowledge surrounding gene editing technologies is highly related to individuals' attitudes toward science, indicating room for future research on examining the directionality of these findings, as well as the relationship between specific knowledge and beliefs toward gene editing. 
We operationalized religiosity as the frequency with which participants attend any religious services, an item that has been used in previous measures of religiosity [Wilkes, Burnett and Howell, 1986]. However, some researchers have examined religiosity through other measures, such as, "how important religion is to you" [Scheufele et al., 2017], which may explain our difference in results. Our one-item measures for religiosity and ideology may be a potential limitation, and future work should replicate these findings using other validated scales.

Our study examines major agricultural stakeholder groups within the U.S. The relationship between gene editing knowledge, value predispositions, and science attitudes may differ in other countries due to a variety of factors. Future work should examine these key variables among stakeholder groups in other countries and global contexts. Further, though there were steps to improve generalizability among the four samples, further research may be necessary to obtain samples that are representative of each population.

This study focused on testing the models of science communication, finding that having more factual knowledge was positively related to attitudes towards science, and conservative ideology was negatively associated with science attitudes. The deficit model has largely been critiqued [Simis et al., 2016] and some research has found evidence against the model's assumptions [Connor and Siegrist, 2010]. Our results reveal that an understanding of new, emerging technologies, such as gene editing, may be positively related to one's attitude toward science, but does not provide a main mechanism that explains how these variables are related. Future work should explore the relationship between other potential variables that may influence science attitudes, such as deference to scientific authority [Brossard and Nisbet, 2007] or attention to media [Marques, Critchley and Walshe, 2015], since information sources may portray science topics in different ways [Calabrese, Anderton and Barnett, 2019; Calabrese, Ding et al., 2020].

Lastly, this was a correlational study, and though we found a strong association between gene editing knowledge and general science attitudes, we cannot make the claim that increased knowledge causally influences positive attitudes. Having more positive attitudes toward science may lead to increased factual knowledge of emerging technologies through increased scientific information seeking, a potential line of research for future studies. Further research should be conducted, such as longitudinal or experimental studies, to examine if there is a causal relationship between knowledge of new technologies and their subsequent attitude toward science.

\section{Conclusion}

This study examines how factual knowledge surrounding an emerging technology, genetic editing, as well as value predispositions, may be associated with general science attitudes among four major agricultural stakeholder groups. We found gene editing and biotechnology knowledge to be significantly related to general science attitudes. Among three of the four groups, conservative ideology was negatively associated with general science attitudes. This study provides an understanding of each stakeholder group's general knowledge level of gene editing technologies. In addition, it serves as a basis for developing engagement strategies with different key publics. While the findings of our study may indicate that informing key publics about gene editing technologies and tailoring messages 
to align with political values may play a role in improving support for science policies, attitudes may remain relatively stable over time. Future work is needed to examine whether specific knowledge plays a role for specific beliefs toward emerging technologies. Other variables related to science attitudes varied by stakeholder group, which sparks questions for future research to understand in what context, when, and how do other factors influence attitudes toward science.

Acknowledgments

This research was funded by the University of California's Innovative Genomics Institute. All authors were funded by IGI.

\section{References}

Allum, N., Sibley, E., Sturgis, P. and Stoneman, P. (2014). 'Religious beliefs, knowledge about science and attitudes towards medical genetics'. Public Understanding of Science 23 (7), pp. 833-849. https://doi.org/10.1177/0963662513492485.

Allum, N., Sturgis, P., Tabourazi, D. and Brunton-Smith, I. (2008). 'Science knowledge and attitudes across cultures: a meta-analysis'. Public Understanding of Science 17 (1), pp. 35-54. https : //doi .org/10 .1177/0963662506070159.

Amoasii, L., Hildyard, J. C. W., Li, H., Sanchez-Ortiz, E., Mireault, A., Caballero, D., Harron, R., Stathopoulou, T.-R., Massey, C., Shelton, J. M., Bassel-Duby, R., Piercy, R. J. and Olson, E. N. (2018). 'Gene editing restores dystrophin expression in a canine model of Duchenne muscular dystrophy'. Science 362 (6410), pp. 86-91. https://doi.org/10.1126/science.aau1549.

Baumgaertner, B., Carlisle, J. E. and Justwan, F. (2018). 'The influence of political ideology and trust on willingness to vaccinate'. PloS ONE 13 (1), e0191728. https://doi.org/10.1371/journal.pone.0191728.

Brossard, D. and Nisbet, M. C. (2007). ‘Deference to scientific authority among a low information public: understanding U.S. opinion on agricultural biotechnology'. International Journal of Public Opinion Research 19 (1), pp. 24-52. https://doi.org/10.1093/ijpor/edl003.

Brossard, D., Scheufele, D. A., Kim, E. and Lewenstein, B. V. (2009). 'Religiosity as a perceptual filter: examining processes of opinion formation about nanotechnology'. Public Understanding of Science 18 (5), pp. 546-558. https://doi.org/10.1177/0963662507087304.

Calabrese, C., Anderton, B. N. and Barnett, G. A. (2019). 'Online representations of "genome editing" uncover opportunities for encouraging engagement: a semantic network analysis'. Science Communication 41 (2), pp. 222-242. https://doi.org/10.1177/1075547018824709.

Calabrese, C., Ding, J., Millam, B. and Barnett, G. A. (2020). 'The uproar over gene-edited babies: a semantic network analysis of CRISPR on Twitter'. Environmental Communication 14 (7), pp. 954-970. https://doi.org/10.1080/17524032.2019.1699135.

Christopherson, E. G., Scheufele, D. A. and Smith, B. (2018). 'The civic science imperative'. Stanford Social Innovation Review. URL: https://ssir.org/articles/entry/the_civic_science_imperative.

Connor, M. and Siegrist, M. (2010). 'Factors influencing people's acceptance of gene technology: the role of knowledge, health expectations, naturalness, and social trust'. Science Communication 32 (4), pp. 514-538. https://doi.org/10.1177/1075547009358919. 
Doxzen, K. and Henderson, H. (2020). 'Is this safe? Addressing societal concerns about CRISPR-edited foods without reinforcing GMO framing'. Environmental Communication 14 (7), pp. 865-871. https://doi.org/10.1080/17524032.2020.1811451.

Fiske, S. T. and Taylor, S. E. (1991). Social cognition. 2nd ed. New York, NY, U.S.A.: McGraw-Hill.

Funk, C. and Hefferon, M. (2018). 'Public views of gene editing for babies depend on how it would be used'. Pew Research Center Science $\mathcal{E}$ Society.

URL: https://www . pewresearch.org/science/2018/07/26/public-views-ofgene-editing-for-babies-depend-on-how-it-would-be-used/.

Funk, C., Rainie, L. and Page, D. (2015). 'Public and scientists' views on science and society'. Pew Research Center Science E Society.

URL: https://www . pewresearch.org/science/2015/01/29/public-and-scien tists-views-on-science-and-society/.

Gaskell, G., Bard, I., Allansdottir, A., da Cunha, R. V., Eduard, P., Hampel, J., Hildt, E., Hofmaier, C., Kronberger, N., Laursen, S., Meijknecht, A., Nordal, S., Quintanilha, A., Revuelta, G., Saladié, N., Sándor, J., Borlido Santos, J., Seyringer, S., Singh, I., Somsen, H., Toonders, W., Torgersen, H., Torre, V., Varju, M. and Zwart, H. (2017). 'Public views on gene editing and its uses'. Nature Biotechnology 35 (11), pp. 1021-1023. https://doi.org/10.1038/nbt.3958.

Ho, S. S., Brossard, D. and Scheufele, D. A. (2008). 'Effects of value predispositions, mass media use, and knowledge on public attitudes toward embryonic stem cell research'. International Journal of Public Opinion Research 20 (2), pp. 171-192. https://doi.org/10.1093/ijpor/edn017.

Kato-Nitta, N., Maeda, T., Inagaki, Y. and Tachikawa, M. (2019). 'Expert and public perceptions of gene-edited crops: attitude changes in relation to scientific knowledge'. Palgrave Communications 5, 137. https://doi.org/10.1057/s41599-019-0328-4.

Kennedy, B., Hefferon, M. and Funk, C. (2018). 'Americans are narrowly divided over health effects of genetically modified foods'. Pew Research Center.

URL: https : / www . pewresearch.org/fact-tank/2018/11/19/americans-arenarrowly-divided-over-health-effects-of-genetically-modified-foods/.

Kohl, P. A., Brossard, D., Scheufele, D. A. and Xenos, M. A. (2019). 'Public views about editing genes in wildlife for conservation'. Conservation Biology 33 (6), pp. 1286-1295. https://doi.org/10.1111/cobi.13310.

Lee, S. and Kim, S.-H. (2018). 'Scientific knowledge and attitudes toward science in South Korea: does knowledge lead to favorable attitudes?' Science Communication 40 (2), pp. 147-172. https://doi.org/10.1177/1075547017753189.

Li, S., Shen, L., Hu, P., Liu, Q., Zhu, X., Qian, Q., Wang, K. and Wang, Y. (2019). 'Developing disease-resistant thermosensitive male sterile rice by multiplex gene editing'. Journal of Integrative Plant Biology 61 (12), pp. 1201-1205. https://doi.org/10.1111/jipb.12774.

Li, T., Liu, B., Spalding, M. H., Weeks, D. P. and Yang, B. (2012). 'High-efficiency TALEN-based gene editing produces disease-resistant rice'. Nature Biotechnology 30 (5), pp. 390-392. https://doi.org/10.1038/nbt. 2199.

Long, C., Amoasii, L., Mireault, A. A., McAnally, J. R., Li, H., Sanchez-Ortiz, E., Bhattacharyya, S., Shelton, J. M., Bassel-Duby, R. and Olson, E. N. (2016). 'Postnatal genome editing partially restores dystrophin expression in a mouse model of muscular dystrophy'. Science 351 (6271), pp. 400-403.

https://doi.org/10.1126/science.aad5725. 
Luskin, R. C. and Bullock, J. G. (2011). “'Don't know" means “Don't know”: DK responses and the public's level of political knowledge'. The Journal of Politics 73 (2), pp. 547-557. https://doi.org/10.1017/S0022381611000132.

Marques, M. D., Critchley, C. R. and Walshe, J. (2015). 'Attitudes to genetically modified food over time: how trust in organizations and the media cycle predict support'. Public Understanding of Science 24 (5), pp. 601-618. https://doi.org/10.1177/0963662514542372.

Miller, J. D. (1983). 'Scientific literacy: a conceptual and empirical review'. Daedalus 112 (2), pp. 29-48. URL: http: //www . jstor.org/stable/20024852.

- (1998). 'The measurement of civic scientific literacy'. Public Understanding of Science 7 (3), pp. 203-223. https://doi .org/10.1088/0963-6625/7/3/001.

Min, Y.-L., Li, H., Rodriguez-Caycedo, C., Mireault, A. A., Huang, J., Shelton, J. M., McAnally, J. R., Amoasii, L., Mammen, P. P. A., Bassel-Duby, R. and Olson, E. N. (2019). 'CRISPR-Cas9 corrects Duchenne muscular dystrophy exon 44 deletion mutations in mice and human cells'. Science Advances 5 (3), eaav4324. https://doi.org/10.1126/sciadv . aav4324.

National Science Board (2018). Science and engineering indicators. Alexandria, VA, U.S.A. URL: https://www.nsf .gov/statistics/indicators/.

Newman, T. P., Nisbet, E. C. and Nisbet, M. C. (2018). 'Climate change, cultural cognition, and media effects: worldviews drive news selectivity, biased processing, and polarized attitudes'. Public Understanding of Science 27 (8), pp. 985-1002. https://doi .org/10.1177/0963662518801170.

Nisbet, M. C. (2018). 'The gene-editing conversation'. American Scientist 106 (1), pp. 15-19. https://doi.org/10.1511/2018.106.1.15.

Post, S. and Maier, M. (2016). 'Stakeholders' rationales for representing uncertainties of biotechnological research'. Public Understanding of Science 25 (8), pp. 944-960. https://doi.org/10.1177/0963662516645039.

Regalado, A. (2018). 'EXCLUSIVE: Chinese scientists are creating CRISPR babies'. MIT Technology Review. URL: https : / www. technologyreview. com/2018/11/25 /138962/exclusive-chinese-scientists-are-creating-crispr-babies/.

Rogers, E. M. (2003). Diffusion of innovations. 5th ed. New York, NY, U.S.A.: Free Press.

Rose, K. M., Howell, E. L., Su, L. Y.-F., Xenos, M. A., Brossard, D. and Scheufele, D. A. (2019). 'Distinguishing scientific knowledge: the impact of different measures of knowledge on genetically modified food attitudes'. Public Understanding of Science 28 (4), pp. 449-467. https://doi.org/10.1177/0963662518824837.

Scheufele, D. A., Xenos, M. A., Howell, E. L., Rose, K. M., Brossard, D. and Hardy, B. W. (2017). 'U.S. attitudes on human genome editing'. Science 357 (6351), pp. 553-554. https://doi.org/10.1126/science.aan3708.

Simis, M. J., Madden, H., Cacciatore, M. A. and Yeo, S. K. (2016). 'The lure of rationality: why does the deficit model persist in science communication?' Public Understanding of Science 25 (4), pp. 400-414. https://doi.org/10.1177/0963662516629749.

Usak, M., Erdogan, M., Prokop, P. and Ozel, M. (2009). 'High school and university students' knowledge and attitudes regarding biotechnology: a Turkish experience'. Biochemistry and Molecular Biology Education 37 (2), pp. 123-130. https://doi.org/10.1002/bmb. 20267.

Walker, B. and Malson, J. (2020). 'Science, God, and nature: a textual and frequency analysis of Facebook comments on news articles about agricultural and environmental gene editing'. Environmental Communication 14 (7), pp. 1004-1016. https://doi.org/10.1080/17524032.2020.1761853. 
Wilkes, R. E., Burnett, J. J. and Howell, R. D. (1986). 'On the meaning and measurement of religiosity in consumer research'. Journal of the Academy of Marketing Science 14 (1), pp. 47-56.

https://doi.org/10.1177/009207038601400107.

Authors

How to cite
Christopher Calabrese (MPH, University of California, Davis, 2016) is a Ph.D. Candidate in the Department of Communication at the University of California, Davis. He is primarily interested in health and science communication, focusing on online network health interventions. His current research focuses on health promotion, social networks, misinformation, and online technologies. E-mail: cjcalabrese@ucdavis.edu.

Jieyu Ding Featherstone (MA, Marquette University, 2016) is a Ph.D. Candidate at the Department of Communication, University of California, Davis. Her current research interests revolve around misinformation and vaccination. She has completed studies in risk communication and sexual health, effects of misinformation on people's vaccination attitudes, conspiracy beliefs and social media use, and the spread of vaccine misinformation on Twitter.

E-mail: jding@ucdavis.edu.

Matthew Robbins (Ph.D., University of California, Davis, 2017) is a Postdoctoral Scholar in the Department of Communication at the University of California, Davis. He is a quantitative environmental social scientist who has studied collaboration in natural resource governance and the science of science communication. E-mail: mjrobbins@ucdavis.edu.

George A. Barnett (Ph.D., Michigan State University, 1976) is a Distinguished Professor Emeritus in the Department of Communication at the University of California, Davis and an International Communication Association (ICA) Fellow. His research primarily concerns with communication and social networks and their application to international communication and the diffusion of innovations. He has served as Chair of the Communication and Technology Division of the ICA and President of the International Network for Social Network Analysis (INSNA). E-mail: gabarnett@ucdavis.edu.

Calabrese, C., Featherstone, J. D., Robbins, M. and Barnett, G. A. (2021). 'Examining the relationship between gene editing knowledge, value predispositions, and general science attitudes among U.S. farmers, scientists, policymakers, and the general public'. JCOM 20 (02), A02. https:/ / doi.org/10.22323/2.20020202. 